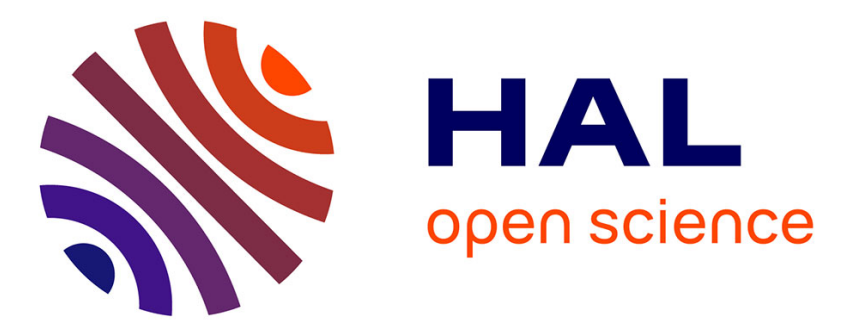

\title{
Vuln-Indices: Software to assess vulnerability to climate change
}

\author{
Romain Lardy, Gianni G. Bellocchi, Raphaël Martin
}

\section{To cite this version:}

Romain Lardy, Gianni G. Bellocchi, Raphaël Martin. Vuln-Indices: Software to assess vulnerability to climate change. Computers and Electronics in Agriculture, 2015, 114, pp.53-57. 10.1016/j.compag.2015.03.016 . hal-02631325

\section{HAL Id: hal-02631325 \\ https://hal.inrae.fr/hal-02631325}

Submitted on 27 May 2020

HAL is a multi-disciplinary open access archive for the deposit and dissemination of scientific research documents, whether they are published or not. The documents may come from teaching and research institutions in France or abroad, or from public or private research centers.
L'archive ouverte pluridisciplinaire HAL, est destinée au dépôt et à la diffusion de documents scientifiques de niveau recherche, publiés ou non, émanant des établissements d'enseignement et de recherche français ou étrangers, des laboratoires publics ou privés. 
Application note

\title{
Vuln-Indices: Software to assess vulnerability to climate change
}

\author{
R. Lardy ${ }^{1}$, G. Bellocchi*, R. Martin \\ Grassland Ecosystem Research Unit, French National Institute for Agricultural Research (INRA), 5 chemin de, 6 Beaulieu, 63039 Clermont-Ferrand, France
}

\section{A R T I C L E I N F O}

\section{Article history:}

Received 5 December 2014

Received in revised form 23 March 2015

Accepted 24 March 2015

\section{Keywords:}

Climate change

Java

Vulnerability indices

\begin{abstract}
A B S T R A C T
Vuln-Indices Java-based software was developed on concepts of vulnerability to climate change of agroecological systems. It implements the calculation of vulnerability indices on series of state variables for assessments at both site and region levels. The tool is useful because synthetic indices help capturing complex processes and prove effective to identify the factors responsible for vulnerability and their relative importance. It is suggested that the tool may be plausible for use with stakeholders to disseminate information of climate change impacts.
\end{abstract}

(c) 2015 Elsevier B.V. All rights reserved.

\section{Introduction}

Vulnerability is the degree to which a human or environmental system is likely to experience harm before being damaged (Turner II et al., 2003). Understanding what potentially unprecedented ecological and climatic changes might do to human well-being and the integrity and functioning of agro-ecosystems is perceived as a central issue in a range of regional and national concerns (Ericksen, 2008). In climate change impact studies, in particular, vulnerability indices are calculated from state variables characterising the system under study and linked to a threshold or a baseline (Lardy et al., 2014). These indices can be generated from simulations under current and altered climate scenarios and used to provide a description of the system performance under climate-change induced hazards or locate vulnerable systems and regions. A line of evolution of vulnerability studies is to enlarge the scale of study (Frazier, 2012), as the complexity in modelling shifts towards applications at progressively larger scales (e.g. Ewert et al., 2011). Maps of vulnerability indices are thus often represented to move from site-based to regional analyses (Metzger and Schröter, 2006; Metzger et al., 2006; Nelson et al., 2010).

To the best of our knowledge, freely available software solutions are not available to compute vulnerability indices in custom developed applications. This paper documents a novel software tool (Vuln-Indices) based on vulnerability concepts from the Intergovernmental Panel on Climate Change (IPCC, 2001) and

\footnotetext{
* Corresponding author. Tel.: +33 4 73624866; fax: +33 473624457.

E-mail addresses: romain.lardy@toulouse.inra.fr (R. Lardy), gianni.bellocchi@ clermont.inra.fr (G. Bellocchi), raphael.martin@clermont.inra.fr (R. Martin).

1 Current address: UMR 5505 IRIT, CNRS, University of Toulouse, 31062 Toulouse, France and UMR 1248 AGIR, INRA-INPT, 31326 Castanet-Tolosan, France.
}

revised by Füssel and Klein (2006). In Section 2, details are provided about the metrics implemented in Vuln-Indices. Examples are considered in Section 3 to illustrate the effectiveness of the indices. Conclusions are drawn in Section 4, where the issue of vulnerability assessment is discussed in the context of current research.

\section{Vulnerability indices and software support}

Lardy et al. (2014) reviewed the indices used in vulnerability studies and proposed their utilization in climate change impact assessments (Table 1 ).

Vuln-Indices Java-based software allows computing vulnerability indices of Table 1 (with an option to extend them) from series of state variables (e.g. time series of simulated annual yields). The tool is meant to perform vulnerability assessment on agro-ecological systems, such as crop and grass-based production systems. Input data contain yearly series of impact variables characterising the system (primary production, harvested yield, etc.), generally obtained via model-based simulations under alternative climate forcing conditions. The main Graphical User Interface (GUI) is based on SWING (http://docs.oracle.com/javase/7/docs/technotes/ guides/swing) and JFreeChart libraries (http://www.jfree.org/jfreechart/) using platform-independent Java language to allow users to load and visualize the input data, as well as display and export outputs in the form of summary tables, histograms and radar scores (Fig. 1). The data formats of input (I) and output (O) files supported are CSV and NetCDF, with export capabilities in Excel and PDF formats.

Comma Separated Values (CSV) is a simple, widely supported (by almost all spreadsheet software and database management 


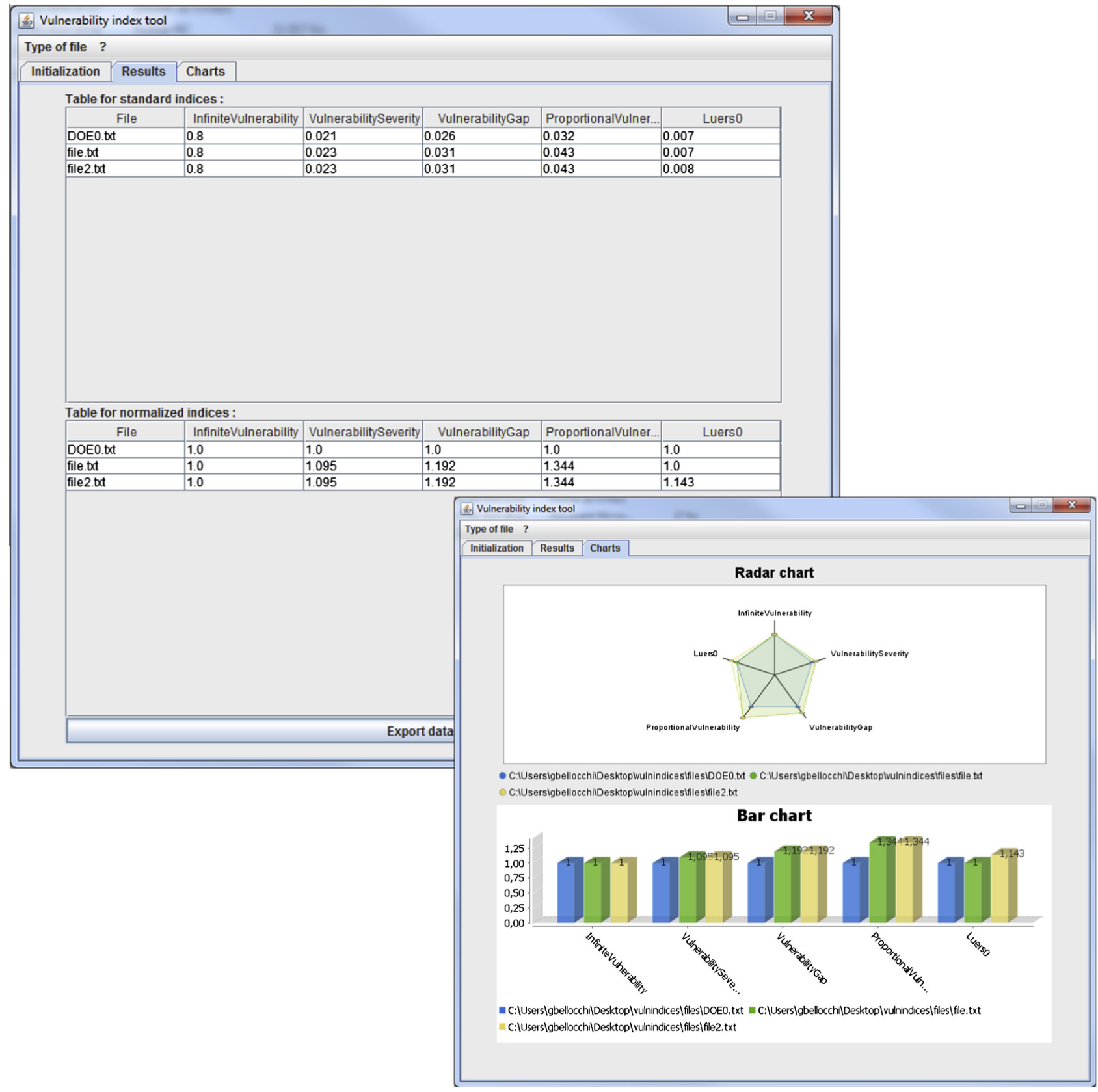

Fig. 1. Screenshot of the Vuln-Indices user interface.

systems) file format. CSV files are meant for site-specific vulnerability assessment. In this case, different sets of projection data can be used to take into account different uncertainty sources (e.g. alternative climate models or downscaling methods), the user being enabled to set weighting factors for expressing the relative probability of each feature at each location.

To facilitate moving from site-based to regional analyses, we use NetCDF file for pixel-based assessments covering large regional areas. The NetCDF (Network Common Data Form, http://www.unidata.ucar.edu/software/netcdf) binary format is a self-describing, compact binary format, used to store and distribute large volumes of data in machine-independent way. The NetCDF files also include embedded information on the spatial grid, making explicit the time dimension (other than latitude and longitude) as well as the units of the gridded variables. A large set of software tools and languages (e.g. R, Matlab, Java, $\mathrm{C}++$ ) have libraries or packages to treat this format, which is used for global and regional simulations provided for the Fifth Assessment Report (AR5) of the IPCC (Williams et al., 2009). NetCDF is already widely used in the community of spatial modelling because it is suitable to handle with pixel-wise data acquired over a defined geographical area. The result of the pixel-based rendering can be displayed in maps of vulnerability indices, as generated by using applications which plot geo-gridded arrays.

One single JAR file is freely distributed together with a file documenting the indices, software design and use.

\section{Illustrative cases}

The numerical examples provided here refer to simulations of European grasslands using the Pasture Simulation model (PaSim, 
Table 1

Vulnerability indices implemented in Vuln-Indices.

\begin{tabular}{|c|c|c|c|}
\hline Index & Equation & Description & Source \\
\hline Proportional vulnerability & $V_{0}=\frac{q}{n}$ & $\begin{array}{l}\text { It corresponds to the ratio of vulnerable individuals to total individuals in a population } \\
\text { (e.g. the proportion of years over a period of time in which agricultural production is } \\
\text { below the threshold) }\end{array}$ & Foster et al. (1984) \\
\hline Vulnerability gap & $V_{1}=\frac{1}{n} \cdot \sum_{t=1}^{q}\left(\frac{W_{0}-W_{t}}{W_{0}}\right)$ & $\begin{array}{l}\text { In a population of individuals, it represents the mean proportion of deficit of vulnerable } \\
\text { individuals from the value selected as threshold (e.g. the difference from the threshold of } \\
\text { below-the-threshold annual production values over a number of years) }\end{array}$ & Foster et al. (1984) \\
\hline Vulnerability severity & $V_{2}=\frac{1}{n} \cdot \sum_{t=1}^{q}\left(\frac{W_{0}-W_{t}}{W_{0}}\right)^{2}$ & $\begin{array}{l}\text { In a population of individuals, it represents the mean proportional distance of vulnerable } \\
\text { individuals from the threshold. The quadratic distance to threshold is used, which gives } \\
\text { more weight to the most vulnerable cases, i.e. the greater the vulnerability is skewed } \\
\text { towards the most vulnerable case (e.g. the least productive year) the greater is the } \\
\text { severity }\end{array}$ & Foster et al. (1984) \\
\hline Most vulnerable individual & $V_{\infty}=1-\frac{\min \left(W_{t}\right)}{W_{0}}$ & $\begin{array}{l}\text { It is the distance from one of the ratio of the state of the most vulnerable case (e.g. the } \\
\text { least productive year) to the threshold. }\end{array}$ & Lardy et al. (2012) \\
\hline Luers-based & $V_{L}=\frac{d W / d X}{\bar{W} / W_{0}}$ & $\begin{array}{l}\text { It accounts for the sensitivity of the system to a stress factor (e.g. changes of agricultural } \\
\text { production with aridity conditions), with respect to a given state. The coefficient of } \\
\text { variation calculated over a series of states (e.g. a time series of agricultural production } \\
\text { values) is adopted here to represent sensitivity (after Lardy et al., 2014) }\end{array}$ & Luers et al. (2003) \\
\hline
\end{tabular}

$q$, number of vulnerable individuals (e.g. number of vulnerable years).

$n$, population size of individuals (e.g. number of years).

$\bar{W}$, average state of the system over a time period (e.g. mean agricultural production over a number of years).

$W_{t}$, state of the system at time $t$ (e.g. agricultural production at a given year).

$W_{0}$, threshold value of the state of the system (e.g. agricultural production below which the system is considered vulnerable).

$d W$, variation of the state of the system over a time period (e.g. variability of agricultural production over a number of years).

$d X$, variation of a climate exposure factor over a time period (e.g. variability of aridity conditions over a number of years).

Ben Touhami et al., 2013; Ma et al., 2015), which is engineered for distributed computing to meet the needs of high-resolution regional simulations (Vital et al., 2013).

\subsection{Site-specific assessment}

Table 2 reports four vulnerability indices calculated upon grassland yields (harvested dry biomass) per year obtained at a low productivity upland permanent pasture in France (Theix; $45^{\circ} 43^{\prime}$ North, $03^{\circ} 01^{\prime}$ East, $850 \mathrm{~m}$ a.s.l.) for three 30 -year time horizons (extracted from a simulation from 1970 to 2099), representative of near past (1970-1999), near future (2020-2049) and far future (2070-2099). The hourly weather data used to force the model were from the SRES-A2 storyline, which envisages high emissions of greenhouse gases as a result of continuous population growth and regionally-oriented economic development (IPCC, 2000). To quantify the probability for the grassland system to incur potentially hazardous climate events, precipitation and temperature hazardous events in each year were quantified via an agro-climatic metric of aridity, $b \geqslant 0$, arid conditions being represented by small values of $b$ (after Diodato and Ceccarelli, 2004). The results show that the overall mean annual yield may increase with climate change. However, a greater chance of exposure to heat and drought stress (shift towards lower b values) may also lead to higher interannual variability (higher standard deviation of yields). The vulnerability indices are presented as both absolute and relative changes with respect to the baseline (time slice 1970-1999). A relative value greater than one is indicative of higher expected vulnerability for adverse climate effects in the future, while a value less than one provides the clue to less vulnerability. Due to the specific construction of the Luers-based index, this normalisation also makes it independent on the threshold setting.

Different vulnerability indices offer complementary insights into the system yet with contrasting views of vulnerability. According to both proportional vulnerability and vulnerability gap (relative values lower than one), the probability for the grassland yields to go down below the threshold value is lower in the future because the distance to the threshold is higher in the past. Vulnerability severity reflects a more complex pattern (relative value lower than one in the near future, higher than one in the far future) depending on the distribution of all of the distances to the threshold. However, in the metrics used by these indices, there is no analytical expression of the sensitivity of the state variable to a change in the climatic hazard. When the sensitivity factor is taken into account (as reflected in the inter-annual variability of climate conditions), as in the Luers-based index, conditions of higher vulnerability are disclosed (relative values higher than one) due to the expectation of more severe aridity conditions in the future.

\subsection{Regional assessment}

The example sketched in Fig. 2 shows the spatial pattern of Luers-based vulnerability index, as obtained by using freeware Panoply Data Viewer (DataONE, 2014). The index was calculated for 2070-2099 on the harvested dry biomass estimated for three intensification scenarios in Europe according to SRES-A1B storyline, in which current trends in emissions continue leading to a doubling in $\mathrm{CO}_{2}$ levels by the end of the 21th century (IPCC, 2000). The simulations (based on a protocol established in the frame of EU-FP7 GHG-Europe, http://www.ghg-europe.eu) were run on $170 \times 278$ grid points at $0.25 \times 0.25^{\circ}$ resolution, spamming from 29.125 to 71.375 latitude North and from 23.875 longitude West to 45.375 longitude East. In some pixels, the index was not calculated (e.g. in some Spanish regions) as the simulated biomass was not sufficient to initiate a harvest. The maps also show the importance of management to influence the vulnerability of grasslands to climate change.

Overall, the IPCC SRES A1B climate change projections to the end of the 21st century are shown to reduce the vulnerability of intensively managed European grasslands (Fig. 2C). The results obtained suggest instead that an increased vulnerability is on average expected with intermediate level of management (Fig. 2B). It is also interesting to see the pattern of regional variations. For instance, climate change is likely driving grassland systems with intermediate management into more vulnerable conditions in a noticeable portion of western France. 
Table 2

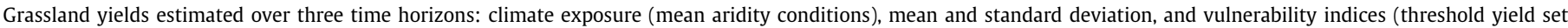
equal to $5 \mathrm{t} \mathrm{DM} \mathrm{ha}^{-1}$ ).

\begin{tabular}{|c|c|c|c|c|c|c|c|c|c|c|c|}
\hline \multirow[t]{3}{*}{ Period } & \multirow{3}{*}{$\frac{\text { Mean yield }}{\text { t DM ha }^{-1}}$} & \multirow[t]{3}{*}{ Standard deviation } & \multirow[t]{3}{*}{ Mean aridity index $(b)^{*}$} & \multicolumn{8}{|c|}{ Vulnerability indices } \\
\hline & & & & \multicolumn{2}{|c|}{$\begin{array}{l}\text { Proportional } \\
\text { vulnerability }\end{array}$} & \multicolumn{2}{|c|}{ Vulnerability gap } & \multicolumn{2}{|c|}{$\begin{array}{l}\text { Vulnerability } \\
\text { severity }\end{array}$} & \multicolumn{2}{|c|}{ Luers-based } \\
\hline & & & & Absolute & Relative & Absolute & Relative & Absolute & Relative & Absolute & Relative \\
\hline 1970-1999 & 4.25 & 0.57 & 29.10 & 0.866 & - & 0.157 & - & 0.034 & - & 0.158 & - \\
\hline 2020-2049 & 4.62 & 0.75 & 27.50 & 0.733 & 0.846 & 0.101 & 0.643 & 0.024 & 0.686 & 0.176 & 1.114 \\
\hline 2070-2099 & 4.45 & 0.81 & 16.50 & 0.733 & 0.846 & 0.130 & 0.828 & 0.036 & 1.052 & 0.205 & 1.297 \\
\hline
\end{tabular}

${ }^{*} b=\frac{1}{2} \cdot\left(\frac{P_{Y}}{T_{Y}+10}+\frac{p_{a}}{T_{a}+10}\right)$ (De-Martonne, 1942): $P_{Y}$ : yearly precipitation total $(\mathrm{mm}), Y_{Y}:$ mean annual temperature $\left({ }^{\circ} \mathrm{C}\right), p_{a}:$ precipitation total of the driest month (mm), $T_{a}$ : mean temperature of the driest month $\left({ }^{\circ} \mathrm{C}\right)$.

(A)

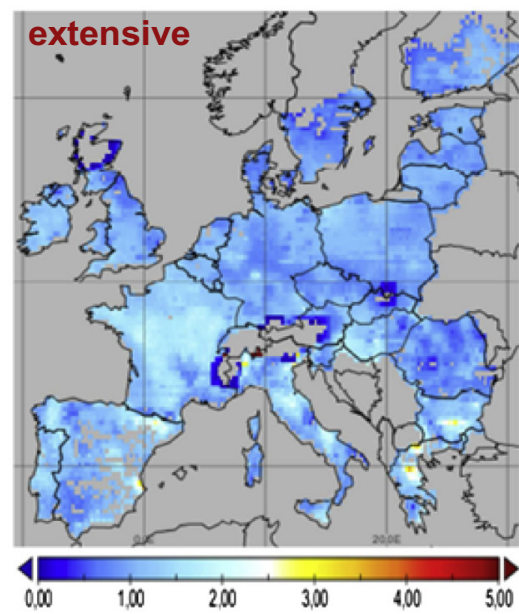

(B)

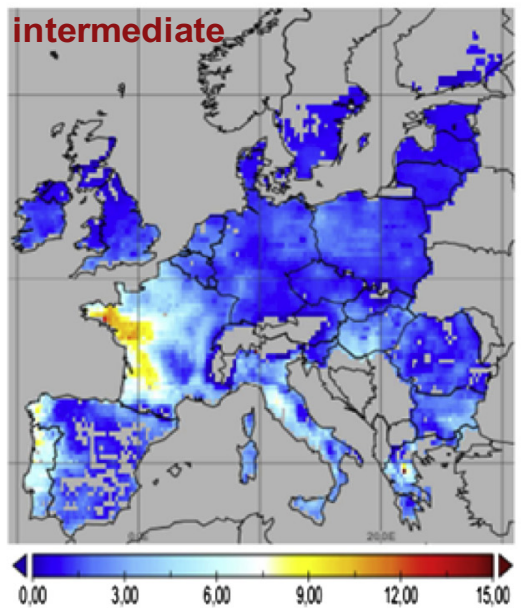

(C)

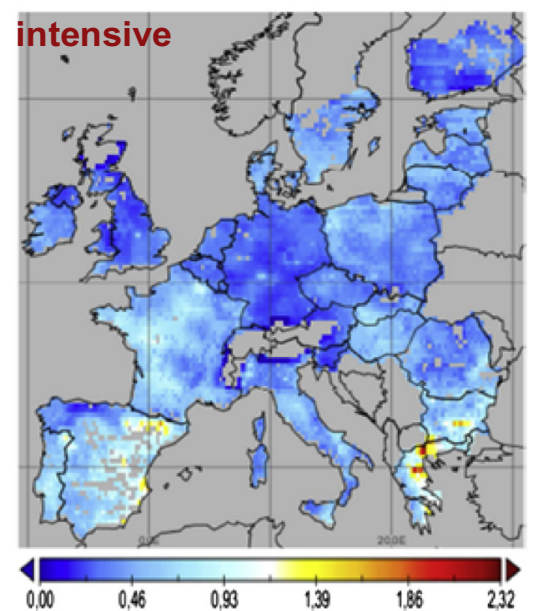

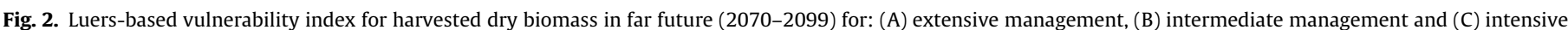

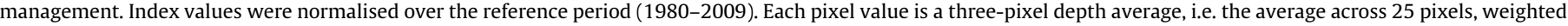
as follows: 0.5 the pixel of interest, 0.3 the eight nearest ones, 0.2 the other 16 pixels (details provided by Lardy (2013), p. 154).

\section{Conclusions}

We propose a software tool to support quantitative(index-based) assessments of vulnerability to climate change (even if the tool is generic enough to be used for other assessments of vulnerability on virtually any kind of systems). Providing usable values of synthetic indices, the approach allows performing model-based inference of agro-ecological systems vulnerability to a variety of climate forcing scenarios, and can be complementary to probability risk analyses (van Oijen et al., 2013, 2014). The approach proposed seeks to combine an index-based scheme with computer-based simulation modelling, both being part of a deliberative process in climate change studies (e.g. Rivington et al., 2007; Bellocchi et al., 2015). In fact, the latter is a useful means of providing new information to stakeholders (land managers and decision makers) about vulnerability to climate change and generating dialogue around its interpretation. With synthetic indices there is the trade-off between the level of detail provided by climate and impact models under sets of conditions and timeliness for decision-making. Integrating the presentation of spatially refined gridded maps with sensitivity to climate, they may support the communication flow of the vulnerabilities and the co-construction of knowledge among scientists and stakeholders (Rivington et al., 2013).

The results presented here are illustrative and, as such are not meant as conclusive findings on the vulnerability of European grasslands. These results, not accounting for the many sources of uncertainties associated with grassland management, emission scenarios, climate and impact modelling, are exemplary of the type of achievement that can be attained in vulnerability analysis based on the use of synthetic indices on both site-specific and regional perspectives. Further developments on model-based vulnerability analyses are certainly needed. The investigation should be extended to the recent scenarios used by the 5th IPCC Assessment Report (IPCC, 2013), while covering the pattern of services (not only marketable yield) provided by agro-ecological systems (thus identifying the vulnerabilities to each service). This kind of action is ongoing, in interaction with stakeholders, under the guidance and conditions laid down by the EU-FP7 project AnimalChange (Bellocchi et al., 2013), and other initiatives aiming at assembling Vuln-Indices and other tools for vulnerability assessment, and automate their linking to high-performance computing tools (Bellocchi et al., 2014).

\section{Software availability}

Name of Software: Vuln-Indices

Developer: Raphaël Martin

Contact Address: INRA, UR0874 Grassland Ecosystem Research, 63039 Clermont-Ferrand, France

Tel.: +33473624872

E-mail: raphael.martin@clermont.inra.fr

Availability: On request to the authors

Cost: free for no-profit use

Program language: Java 


\section{Acknowledgements}

Vuln-Indices Java-based software was developed with funding from the European Community's Seventh Framework Programme (FP7/2007-2013) under the Grant agreement No. 266018 (AnimalChange). It was also supported by the research grant (Bourse Recherche Filière) of the region Auvergne of France (financed by the European Regional Development Fund), within the frame of an international research project named "FACCE MACSUR Modelling European Agriculture with Climate Change for Food Security, a FACCE JPI knowledge hub". Claude Mazel (Blaise Pascal University, LIMOS, Aubière, France) is acknowledged for his support.

\section{References}

Bellocchi, G., Lardy, R., Martin, R., 2013. The European pasture sensitivity to climate change. AnimalChange E-Newsletter, November 2013. <http://www. animalchange.eu/docs/newsletter_Nov2013.pdf> (accessed 22.03.2015).

Bellocchi, G., Martin, R., Shtiliyanova, A., Ben Touhami, H., Carrère, P., 2014. Vul'Clim - Climate change vulnerability studies in the region Auvergne (France). FACCE MACSUR Mid-term Scientific Conference, "Achievements, Activities, Advancement”, April 01-04, Sassari, Italy <http://ocs.macsur.eu/index.php/ Hub/Mid-term/paper/view/209/15> (accessed 22.03.2015).

Bellocchi, G., Rivington, M., Matthews, K., Acutis, M., 2015. Deliberative processes for comprehensive evaluation of agroecological models. A review. Agronomy Sustain. Dev. 35, 589-605.

Ben Touhami, H., Lardy, R., Barra, V., Bellocchi, G., 2013. Screening parameters in the Pasture Simulation model using the Morris method. Ecol. Model. 266, 42-57.

DataONE, 2014. Panoply data viewer. Data Observation Network for Earth, Albuquerque, NM. http://www.dataone.org/software-tools/panoply-dataviewer> (accessed 22.03.2015).

De Martonne, E., 1942. Nouvelle carte mondiale de l'indice d'aridité. Annales de Géographie 51, 242-250 (in French).

Diodato, N., Ceccarelli, M., 2004. Multivariate indicator Kriging approach using a GIS to classify soil degradation for Mediterranean agricultural lands. Ecol. Indic. 4 $177-187$.

Ericksen, P.J., 2008. What is the vulnerability of a food system to global environmental change? Ecol. Soc. 13, 14

Ewert, F., van Ittersum, M.K., Heckelei, T., Therond, O., Bezlepkina, I., Andersen, E., 2011. Scale changes and model linking methods for integrated assessment of agri-environmental systems. Agr. Ecosyst. Environ. 142, 6-17.

Foster, J., Greer, J., Thorbecke, E., 1984. A class of decomposable poverty measures. Econometrica 52, 761-766.

Frazier, T.G., 2012. Selection of scale in vulnerability and resilience assessments. J. Geogr. Nat. Disasters 2, e108.

Füssel, H.-M., Klein, R.J.T., 2006. Climate change vulnerability assessments: an evolution of conceptual thinking. Clim. Change 75, 301-329.

IPCC, 2000. A1 Storyline and Scenario Family. In: Nakičenovič, N., Swart, R. (Eds.), Summary for Policymakers, Intergovernmental Panel of Climate Change, Geneva. <http://www.ipcc.ch/ipccreports/sres/emission/index.php?idp=93> (accessed 22.03.2015).

IPCC, 2001. Climate change 2001: impacts, adaptation, and vulnerability. Third Assessment Report of the Intergovernmental Panel on Climate Change. Cambridge University Press, Cambridge, United Kingdom, 1032 p.

IPCC, 2013. IPCC 5th Assessment Report Climate Change 2013: the Physical Science Basis. University Press, Cambridge, UK. <http://www.ipcc.ch/report/ar5/wg1/\#. Uk701xBvCVq> (accessed 22.03.2015).
Lardy, R., 2013. Calcul intensif pour l'évaluation de la vulnérabilité en utilisant une approche d'Ingénierie Dirigée par les Modèles. Application à la vulnérabilité des prairies au changement climatique sous contraintes de plans d'expériences. $\mathrm{PhD}$ thesis, Blaise Pascal University, Clermont-Ferrand, France, p. 258. (in French).

Lardy, R., Martin, R., Bachelet, B., Hill, D., R., C., Bellocchi, B., 2012. Ecosystem climate change vulnerability assessment framework. In: Seppelt, R., Voinov, A.A., Lange, S., Bankamp, D. (Eds.), Proceedings of the International Environmental Modelling and Software Society (iEMSs) 2012 International Congress on Environmental Modelling and Software. Managing Resources of a Limited Planet: Pathways and Visions under Uncertainty, Sixth Biennial Meeting, 1-5 July, Leipzig, Germany. pp. 777-784.

Lardy, R., Bachelet, B., Bellocchi, G., Hill, D.R.C., 2014. Towards vulnerability minimization of grassland soil organic matter using metamodels. Environ. Model. Softw. 52, 38-50.

Luers, A.L., Lobell, D.B., Sklar, L.S., Addams, C.L., Matson, P.M., 2003. A method for quantifying vulnerability, applied to the agricultural system of the Yaqui Valley, Mexico. Global Environ. Change 13, 255-267.

Ma, S., Lardy, R., Graux, A.-I., Ben Touhami, H., Klumpp, K., Martin, R., Bellocchi, G., 2015. Regional-scale analysis of carbon and water cycles on managed grassland systems. Environ. Model. Softw. http://dx.doi.org/10.1016/j.envsoft.2015. 03.007.

Metzger, M.J., Schröter, D., 2006. Towards a spatially explicit and quantitative vulnerability assessment of environmental change in Europe. Regional Environ. Change 6, 201-216.

Metzger, M.J., Rounsevell, M.D.A., Acosta-Michlik, L., Leemans, R., Schröter, D., 2006 The vulnerability of ecosystem services to land use change. Agr. Ecosyst. Environ. 114, 69-85.

Nelson, R., Kokic, P., Crimp, S., Martin, P., Meinke, H., Howden, S.M., 2010. The vulnerability of Australian rural communities to climate variability and change: Part II-integrating impacts with adaptive capacity. Environ. Sci. Policy 13, 1827.

Rivington, M., Matthews, K.B., Bellocchi, G., Buchan, K., Stöckle, C.O., Donatelli, M., 2007. An integrated assessment approach to conduct analyses of climate change impacts on whole-farm systems. Environ. Model. Softw. 22, 202-210.

Rivington, M., Matthews, K.B., Buchan, K., Miller, D.G., Bellocchi, G., Russell, G., 2013. Climate change impacts and adaptation scope for agriculture indicated by agrometeorological metrics. Agr. Syst. 114, 15-31.

Turner II, B.L., Kasperson, R.E., Matson, P.A., Mccarthy, J.J., Corell, R.W., Christensen, L., Eckley, N., Kasperson, J.X., Luers, A., Martello, M.L., Polsky, C., Pulsipher, A. Schiller, A., 2003. A framework for vulnerability analysis in sustainability science. In: Proceedings of the National Academy of Sciences of the United States of America 100, pp. 8074-8079.

Van Oijen, M., Beer, C., Cramer, W., Rammig, A., Reichstein, M., Rolinski, S., Soussana, J.-F., 2013. A novel probabilistic risk analysis to determine the vulnerability of ecosystems to extreme climatic events. Environ. Res. Lett 8, 015032.

Van Oijen, M., Balkovič, J., Beer, C., Cameron, D., Ciais, P., Cramer, W., Kato, T. Kuhnert, M., Martin, R., Myneni, R., Rammig, A., Rolinksi, S., Soussana, J.-F., Thonicke, K., Van der Velde, M., Xu, L., 2014. Impact of droughts on the C-cycle in European vegetation: a probabilistic risk analysis using six vegetation models. Biogeosci. Discuss. 11, 8325-8371.

Vital, J.-A., Gaurut, M., Lardy, R., Viovy, N., Soussana, J.-F., Bellocchi, G., Martin, R., 2013. High-performance computing for climate change impact studies with the Pasture Simulation model. Comput. Electron. Agr. 98, 131-135.

Williams, D.N., Ananthakrishnan, R., Bernholdt, D.E., Barathi, S., Brown, D., Chen, M., Chervenak, A.L., Cinquini, L., Drach, R., Foster, I.T., Fox, P., Fraser, D., Garcia, J., Hankin, S., Jones, P., Middleton, D.E., Schwidder, J., Schweitzer, R., Schuler, R., Shoshani, A. Siebenlist, F., Sim, A., Strand, W.G., Su, M., Wilhelmi, N.C., 2009. The Earth System Grid: enabling access to multimodel climate simulation data. Bull. Am. Meteorol. Soc. 90, 195-205. 